УДК 338.2

\title{
ФАКТОРИ ВИНИКНЕННЯ КРИЗОВИХ ЯВИЩ ТА ЗАБЕЗПЕЧЕННЯ СТАЛОГО РОЗВИТКУ ПІДПРИЕМСТВА
}

\section{FACTORS OF CRISIS AND PROVISION OF SUSTAINABLE DEVELOPMENT OF THE ENTERPRISE}

\author{
Хринюк Олексій Сергійович \\ кандидат економічних наук, доцент, \\ Національний технічний університет України \\ «Київський політехнічний інститут імені Ігоря Сікорського» \\ ORCID: https://orcid.org/0000-0003-4705-9854 \\ Очеретяна Олександра Вадимівна \\ магістрант, \\ Національний технічний університет України \\ «Київський політехнічний інститут імені Ігоря Сікорського» \\ ORCID: https://orcid.org/0000-0002-8443-5997
}

\author{
Khryniuk Oleksii, Ocheretiana Oleksandra \\ National Technical University of Ukraine \\ «lgor Sikorsky Kyiv Polytechnic Institute»
}

\begin{abstract}
У статті розглянуто ключові підходи до визначення поняття «криза підприємства», що уже зустрічалися у вітчизняній науковій літературі, а також вперше визначено три підходи до трактування поняття «сталий розвиток підприємства». Проведено порівняння цих термінів та визначено, що за своєю сутнісною характеристикою вони не мають спільних ознак окрім того, що сприяють змінам на підприємстві (у першому випадку - негативним, у другому - позитивним). Далі було проведено огляд сракторів виникнення кризових явищ та фракторів забезпечення сталого розвитку підприємства. В межах наведених класифікацій виділено групи подібних фракторів та проведено їхній детальний порівняльний аналіз. На основі зробленого висновку про те, що криза та сталий розвиток мають схожі фактори, було зроблено припущення про те, що підприємства які впроваджують стандарти сталого розвитку у свою діяльність, є менш вразливими до кризових явищ.

Ключові слова: криза, сталий розвиток, фрактори, фрактори виникнення кризових явищ, фрактори впливу на сталий розвиток.
\end{abstract}

В статье рассмотрены ключевые подходы к определению понятия «кризис предприятия», что уже встречались в украинской научной литературе, а также впервые определено три подхода к трактовке понятия «устойчивое развитие предприятия». Проведено сравнение этих терминов и определено, что по своей сущностной характеристикой они не имеют ничего общего кроме того, что способствуют изменениям на предприятии (в первом случае - отрицательным, во втором - положительным). Далее был проведен обзор факторов возникновения кризисных явлений и фракторов влияния на устойчивое развитие предприятия. В пределах указанных классификаций выделены группы подобных факторов и проведен их детальный сравнительный анализ. На основе сделанного вывода о том, что кризис и устойчивое развитие имеют одинаковые фракторы проявления, было сделано предположение о том, что предприятия внедряющих стандарты устойчивого развития в свою деятельность, менее уязвимыми к кризисным явлениям.

Ключевые слова: кризис, устойчивое развитие, фракторы, фракторы возникновения кризисных явлений, фракторы влияния на устойчивое развитие.

The purpose of this article is to determine the interrelation between the concepts and factors of crisis and the impact on the sustainable development of the enterprise. In addition to the main operating activity, modern enterprises must also carry out a significant list of other activities. The relevance of this study is due to the need to optimize the 
financial and labor resources of the enterprise for other activities. It is expected that the root causes of the crisis in the enterprise and the drivers of sustainable development may be similar or intersect. The article considers the key approaches to defining the concept of "enterprise crisis", which have already occurred in the Ukrainian scientific literature. The authors have developed their own three approaches to the interpretation of the concept of "sustainable development of the enterprise". A comparison of these terms is made and it is determined that by their essential characteristics they have nothing in common except that they contribute to changes in the enterprise (in the first case negative, in the second - positive). Next, a review of the factors of crisis phenomena and factors influencing the sustainable development of the enterprise. It has been found that the factors of crisis phenomena are usually divided into internal and external. They have many levels of detail. Factors influencing the sustainable development of the enterprise are also detailed to conduct a better analysis of the achieved level of sustainable development. Within the above classifications, the authors of the article identified two groups of similar factors, numbering six subgroups in each. Then a detailed comparative analysis was performed. It is concluded that the same indicators, tools, measures, and methods of enterprise management in case of reduced efficiency or inefficient use are factors of crisis phenomena, and in case of increased efficiency and improvement - factors of positive impact on sustainable development of the enterprise. The results of this study also created a new hypothesis that companies that successfully implement sustainable development standards in their activities are more resilient to crises. Proving this hypothesis in practice will be the next stage of the study.

Keywords: crisis, sustainable development, factors, factors of crisis phenomena, factors influencing sustainable development.

Постановка проблеми. В своїй діяльності підприємства завжди остерігалися кризових явищ, здійснювали активні антикризові політики, проводили постійний моніторинг внутрішніх та зовнішніх ризиків. Віднедавна до бажаних напрямів активностей підприємства було додано сталий розвиток. Таким чином, окрім операційної діяльності, яка $€$ головною метою створення підприємства та яка зазвичай приносить найбільшу частку прибутку, сучасному бізнесу необхідно здійснювати значний перелік інших видів діяльності.

Для оптимізації фрінансових та трудових ресурсів підприємства на здійснення іншої та управлінської діяльності, необхідно з'ясувати чи не дублюються новостворені виклики з уже відомими, тобто у даному прикладі - з'ясувати та порівняти першопричини виникнення кризових явищ на підприємстві та рушії для сталого розвитку, а в подальшій роботі - співставити програми антикризового управління та управління сталим розвитком підприємства.

Аналіз останніх досліджень і публікацій. В економічній літературі сутнісна характеристика кризи підприємства розглядалася у працях багатьох вітчизняних вчених, серед них Базаров Г.З., Бірюкова О.Ю., Белих Л.П., Бєляєва С.Т., Василенко В.О., Гринчишин Я.М., Гудзь Т.П., Карпунь.Н., Кован С.Е., КорольВ.С., Коротков Є.М., Кошкін В.І., Крутік А.Б., Мокрова А.Н., Прокопишак В.Б., Сич О.А., Терещенко О.О., Чернявський А.Д., Хавін Д.В., Яресь О.Б. Фактори виникнення кризових явищ досліджували Возний С.В., Гаврилко П.П., Головач К.С., Колодійчук А.В, Лалакулич М.Ю., Тюріна Н.М. та інші.
Щодо поняття сталого розвитку підприємства, то його вивчали такі вітчизняні вчені як Бурда А.І., Варченко О.М., Васильчук І.П, Васюткіна Н.В, Гайдатов О.В., Глинська А.Є., Камінській П.Д., Квятковська Л.А, Коверга С.В., Кучерова Е.Н., Михайлова А.Е., Ніценко В.С, Сизоненко О.О., Семенюк О.М., Сталинська О.В., Чорних А.В., Шубравська О.В. Дослідження фракторів впливу на сталий розвиток підприємства розглядали Квятковська Л.А., Самофатова В.А., Федоренко Т.М. та інші.

Виділення невирішених раніше частин загальної проблеми. Аналіз доробку вітчизняних вчених свідчить про те, що поняття «кризи підприємства» та «сталого розвитку підприємства» широко розглянуті в науковій літературі поодинці, але не має жодного дослідження, у якому б співставлялися ці поняття та виокремлювалися гіпотези про їхній взаємозв'язок та вплив одне на одного.

Формулювання цілей статті. Метою дослідження $€$ визначення взаємозв'язку між поняттями «криза підприємства» та «сталий розвиток підприємства», а також між фракторами виникнення кризових явищ та фракторами забезпечення сталого розвитку підприємства.

Виклад основного матеріалу дослідження. Для визначення взаємозв'язку між досліджуваними фракторами спочатку потрібно дослідити сутність понять «криза» та «сталий розвиток».

Термін «криза» (від грец. krisis - поворотний пункт) використовується вченими уже дуже давно і налічує сотні десрініцій, однак Гринчишин Я.М. виділяє серед всієї цієї сукупності лише три підходи для визначення 
поняття «криза підприємства» [1]. На думку вченого, перша група науковців розглядає кризу підприємства як процес, що виникає несподівано та обмежує діяльність підприємства; друга група науковців вважає, що криза - пік накопичення невирішених проблем підприємства; третя група розглядає кризу як одну із фраз життєвого циклу, що є неминучою в діяльності підприємства (рис. 1).

Термін «сталий розвиток» відносно новий в економіці. Вперше він був використаний прем'єр-міністром Норвегії Брундтландом Г.Х. у 1987 році у звіті Міжнародної комісії 3 навколишнього середовища і розвитку «Наше спільне майбутнє». В його розумінні це такий розвиток, що задовольняє потреби теперішнього та не загрожує задоволенню потреб майбутніх поколінь [3].

Для розуміння сталого розвитку у підприємництві також сорормовано значну кількість визначень. На прикладі узагальнення підходів до розуміння терміну «криза підприємства», авторами було самостійно розроблено три підходи до розуміння терміну «сталий розвиток підприємства» на основі аналізу дефрініцій вітчизняних вчених (рис. 2). Перша група вчених розглядають сталий розвиток підприємства як успішне втілення однойменної концепції; друга група вважають, що сталий - це динамічний, збалансований, регульований розвиток, який здійснюється у активній взаємодії із зовнішнім та внутрішнім середовищем підприємства; третя група трактують сталий розвиток як постійний незмінний рівень фрінансової ефрективності та цілісності підприємства в умовах змінності навколишнього середовища.
Дослідивши підходи до трактування понять «криза підприємства» та «сталий розвиток підприємства», можемо зазначити, що ці терміни ніяк не перетинаються в своїх визначеннях. Криза розглядається здебільшого як проблема для підприємства (рідше - як нова можливість), що обмежує його звичний темп життєдіяльності та вимагає негайного реагування від керівних органів. Сталий розвиток підприємства навпаки починається із управлінського рішення, створення певної програми чи стратегії. Він завжди передбачає нові можливості, а прояви сталого розвитку на підприємстві мають позитивні результати і допомагають реагувати на зовнішні виклики.

Поняття «фрактор» або «чинник» використовуються для визначення причин та умов виникнення будь-яких процесів. Тому, проаналізувавши та порівнявши фрактори виникнення кризових явищ та фрактори впливу на сталий розвиток підприємства, можемо з'ясувати спільне у природі цих двох економічних явищ.

Гаврилко П.П., Лалакулич М.Ю. та Колодійчук А.В. розробили чотирьохрівневу класифікацію фракторів виникнення кризових явищ на промислових підприємствах. Перший рівень деталізації передбачає поділ на зовнішні та внутрішні чинники. На другому рівні - в межах зовнішніх виділяються міжнародні (загальноекономічні, стабільність міжнародної політики, міжнародна конкуренція), національні (політичні, економічні та демографрічні) та ринкові фрактори (форми конкуренції, науковотехнічні), а в межах внутрішніх - конкурентні, чинники діяльності, ресурсні, маркетингові, фрінансові, управлінські та інноваційні. Чет-

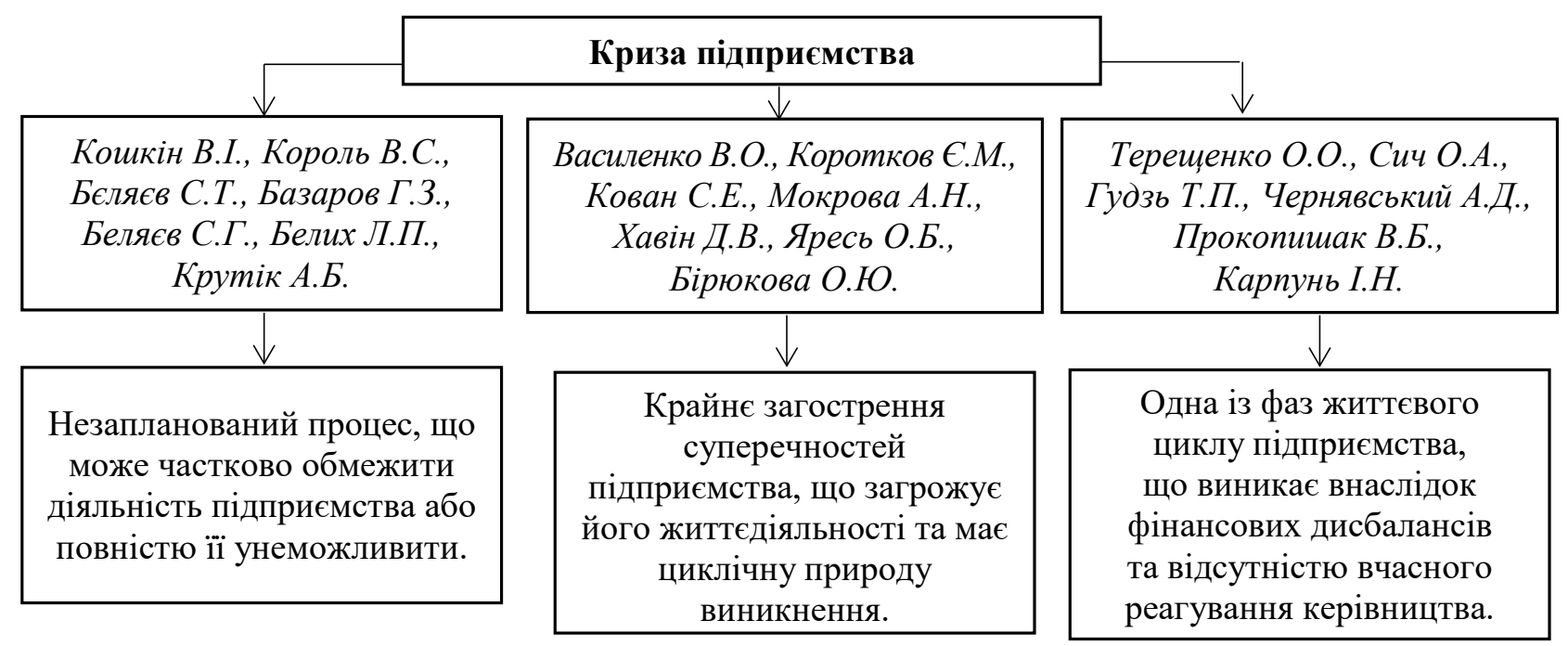

Рис. 1. Підходи до визначення поняття «криза підприємства» 


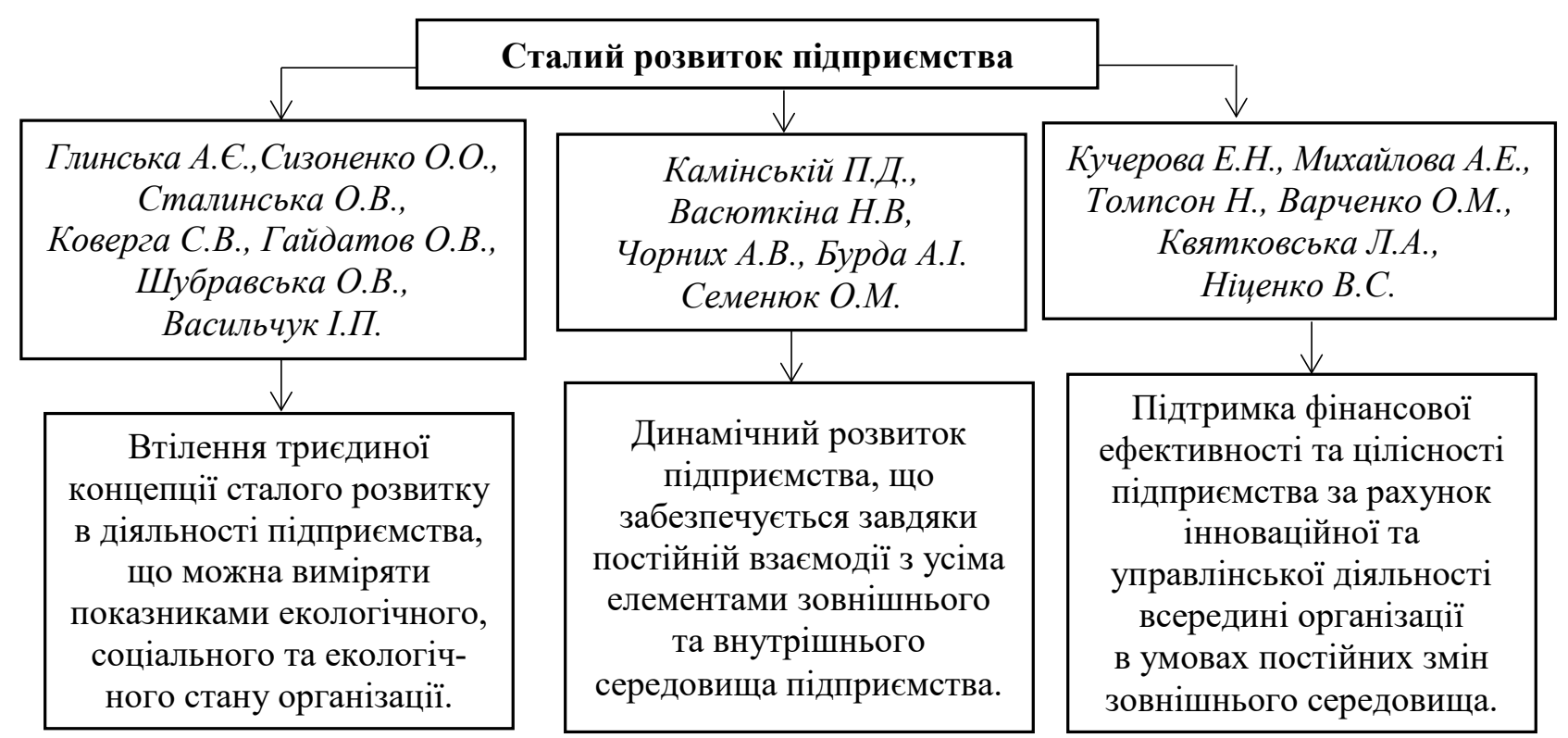

Рис. 2. Підходи до визначення поняття «сталий розвиток підприємства»

Джерело: складено на основі [3; 4]

вертий рівень цієї класифрікації представлений конкретними показниками, інструментами діяльності, заходами та методами управління підприємством [5].

В своїй роботі Головач К.С. виокремив екзогенні (зовнішні) та ендогенні (внутрішні) кризові фрактори. До першої групи було віднесено фрінансово-економічні, соціальні, ринкові, політичні та технологічні фрактори, а до другої групи - управлінські, фрінансові, кадрові, виробничі, маркетингові/ збутові та інсрормаційні. Також в роботі наголошується, що екзогенні та ендогенні чинники діють комплексно, а не самостійно. Зовнішні фрактори розглядаються як передумови та/або стимулятори для загострення внутрішніх фракторів [6].

Дещо інший підхід демонструють Возний С.В. та Тюріна Н.М., які виділяють комплекс фракторів виникнення кризових явищ, що включає природні, екологічні, політичні, виробничо-технічні, соціальні, а також срактори невизначеності та глобалізації. Важливість останнього, вони пояснюють неспроможністю нестабільних економічно та політично держав отримувати позитивні наслідки від процесів світової глобалізації [7].

Отже, вітчизняні науковці зазвичай виділяють складну класифрікацію фракторів виникнення кризових явищ, яка на першому рівні поділяє фрактори на екзогенні та ендогенні, а на нижчих рівнях намагається охопити різноманітні причини виникнення кожного окремого виду кризи на підприємстві. Також в роботах йдеться про негативний синергетичний ефрект від взаємодії одразу всіх чи кількох фракторів виникнення кризових явищ.

Щодо фракторів, які забезпечують сталий розвиток суб'єктів ринку, то Федоренко Т.М. поділяє їх на п'ять груп, а саме природно-географрічні, фрінансово-економічні, соціально-економічні, політичні та матеріально-технічні. Також вона наголошує на важливості розмежування цих сракторів при аналізі на кількісні та якісні [8].

На думку Самофратової В.А. доцільно розглядати фрактори забезпечення сталого розвитку підприємства, розділивши їх на тринадцять груп: природно-ресурсні, демографрічні, економічні, соціальні, трудові і підприємницькі, фрінансові, екологічні, інноваційні, інфрраструктурні, наукові, організаційні, інституціональні, форс-мажорні. Вчена вважає, що така деталізація необхідна для глибокого аналізу всієї сукупності фракторів та для подальшої розробки напрямків вдосконалення сталого розвитку на підприємстві [9].

В науковій літературі часто зустрічається поділ сракторів забезпечення сталого розвитку підприємства на внутрішні та зовнішні. Однак, Квятковська Л.А. розширила цю класифрікацію виділивши підгрупи: в межах зовнішніх фракторів - загальноекономічні, ринкові та інші, а в межах внутрішніх - операційні, інвестиційні та фрінансові. Це $є$ умовою для проведення фракторного аналізу ефрективності обраної стратегії підприємства щодо досягнення бажаного рівня сталого розвитку [10]. 
Аналіз здобутків вчених показав, що фрактори забезпечення сталого розвитку підприємства виділяються у трьох напрямках відповідно до складових концепції сталого розвитку: економічної, соціальної та екологічної. Також спільним у роботах вчених $є$ ствердження про необхідність глибокої деталізації фракторів на групи та підгрупи для якісного аналізу поточного рівня сталого розвитку на підприємстві та подальшого розвитку стратегії.

Розглянувши значний обсяг класифрікацій фракторів виникнення кризових явищ та фракто- рів забезпечення сталого розвитку підприємства, можемо виділити спільні групи чинників та порівняти їхні прояви в межах досліджуваних напрямків (табл. 1).

Отже, було виділено дві групи фракторів внутрішні та зовнішні, в межах яких розглянуто ще по шість підгруп. Їхні прояви в аспекті кризових явищ та в аспекті сталого розвитку можна вважати дзеркальними. Це означає, що одні й ті самі показники, інструменти діяльності, заходи та методи управління підприємством у випадку зменшення результа-

Таблиця 1

Порівняльна характеристика груп фракторів виникнення кризових явищ та груп факторів забезпечення сталого розвитку підприємства

\begin{tabular}{|c|c|c|}
\hline $\begin{array}{c}\text { Група } \\
\text { факторів }\end{array}$ & Прояв в аспекті кризових явищ & Прояв в аспекті сталого розвитку \\
\hline \multicolumn{3}{|c|}{ Зовнішні (екзогенні) фактори } \\
\hline Економічні & $\begin{array}{l}\text { Серед економічних фракторів - } \\
\text { високий рівень іноляції, зростання } \\
\text { державного боргу, зниження реальних } \\
\text { доходів населення, циклічність } \\
\text { економічного розвитку, відсутність } \\
\text { розвитку страхових послуг тощо. }\end{array}$ & $\begin{array}{l}\text { Характеризуються приростом } \\
\text { внутрішнього валового продукту на } \\
\text { душу населення, зниження рівня } \\
\text { інфрляції, стабілізація податкової } \\
\text { системи, підвищення рівня } \\
\text { платоспроможності населення тощо. }\end{array}$ \\
\hline Ринкові & $\begin{array}{l}\text { Проявляються як руйнування } \\
\text { ринків збуту продукції, низький } \\
\text { рівень підприємницької активності } \\
\text { на ринку, незбалансованість } \\
\text { попиту та пропозиції на ринку, } \\
\text { ринкова монополізація, некерована } \\
\text { конкурентна боротьба тощо. }\end{array}$ & $\begin{array}{l}\text { Фактори, що описують збільшення } \\
\text { кількості суб'єктів ринку, зростання } \\
\text { внутрішнього попиту, стабілізація } \\
\text { валютного ринку, перевищення } \\
\text { експорту над імпортом, зростання } \\
\text { активності ринку тощо. }\end{array}$ \\
\hline Політичні & $\begin{array}{l}\text { Характеризуються через ставлення } \\
\text { держави до підприємництва, } \\
\text { політичну (не)стабільність всередині } \\
\text { країни, неврегульовану законодавчу } \\
\text { базу , рівень налагодженості } \\
\text { міжнародних відносин, захист } \\
\text { конкуренції, антимонопольне } \\
\text { регулювання тощо. }\end{array}$ & $\begin{array}{l}\text { Проявляються як захист прав } \\
\text { та свобод громадян, політична } \\
\text { стабільність, підтримка } \\
\text { підприємництва, врегулювання } \\
\text { міжнародних відносин, позитивні } \\
\text { ефекти від глобалізації тощо. }\end{array}$ \\
\hline Соціальні & $\begin{array}{l}\text { Описуються за допомогою показників } \\
\text { рівня доходів та рівня нагромаджень } \\
\text { населення, недовіри до вітчизняного } \\
\text { товаровиробника, підвищення рівня } \\
\text { міграції та безробіття тощо. }\end{array}$ & $\begin{array}{l}\text { Фактори, що описують рівень та якість } \\
\text { життя населення, забезпеченість } \\
\text { житлом, доступність до освіти, } \\
\text { можливість працевлаштування, } \\
\text { збільшення платоспроможності } \\
\text { населення, покращення пенсійної } \\
\text { системи тощо. }\end{array}$ \\
\hline Демографрічні & $\begin{array}{l}\text { Описуються за допомогою негативних } \\
\text { демографрічних тенденцій як в } \\
\text { країні, так і в конкретному регіоні, } \\
\text { підвищення смертності, міграція } \\
\text { висококваліфрікованих працівників } \\
\text { тощо. }\end{array}$ & $\begin{array}{l}\text { Описуються за допомогою позитивних } \\
\text { демографрічних тенденцій, наприклад } \\
\text { збільшення чисельності населення, } \\
\text { зменшення міграцій, стабілізація } \\
\text { вікової та гендерної структур тощо. }\end{array}$ \\
\hline Наукові & $\begin{array}{l}\text { Характеризуються технологічним } \\
\text { застоєм, низькими витратами } \\
\text { держави на науку, екстенсивним } \\
\text { розвитком підприємництва, низький } \\
\text { рівень захисту інтелектуальної } \\
\text { власності в країні тощо. }\end{array}$ & $\begin{array}{l}\text { Серед наукових фракторів - сприяння } \\
\text { розвитку НДДКР у державі, співпраця } \\
\text { науково-дослідних та навчальних } \\
\text { установ з підприємствами, створення } \\
\text { наукових центрів, технопарків тощо. }\end{array}$ \\
\hline
\end{tabular}


(Закінчення таблиці 1)

\begin{tabular}{|c|c|c|}
\hline $\begin{array}{c}\text { Група } \\
\text { фракторів }\end{array}$ & Прояв в аспекті кризових явищ & Прояв в аспекті сталого розвитку \\
\hline \multicolumn{3}{|c|}{ Внутрішні (ендогенні) фрактори } \\
\hline Фінансові & $\begin{array}{l}\text { Фінансові фрактори характеризуються } \\
\text { структурою балансу підприємства, } \\
\text { зниженням ділової активності, } \\
\text { фрінансової стійкості, ліквідності, } \\
\text { зниження рівня прибутку та } \\
\text { рентабельності, неефективна робота } \\
\text { з кредиторами та дебіторами тощо. }\end{array}$ & $\begin{array}{l}\text { Характеризуються ефрективністю } \\
\text { фрінансової стратегії підприємства, } \\
\text { позитивною дохідністю та } \\
\text { рентабельністю, мінімізацією } \\
\text { фрінансових ризиків, наявністю } \\
\text { ефективного фрондового портфрелю } \\
\text { тощо. }\end{array}$ \\
\hline Трудові & $\begin{array}{l}\text { Описуються як низький рівень } \\
\text { контролю за діяльністю працівників, } \\
\text { неефективний розподіл робочого часу } \\
\text { працівників, відсутність мотиваційних } \\
\text { схем, конфрлікти всередині колективу, } \\
\text { неефективна кадрова політика тощо. }\end{array}$ & $\begin{array}{l}\text { Описуються як наявність обліку } \\
\text { робочого часу, моніторинг зайнятості } \\
\text { та відпочинку працівників, } \\
\text { система делегування обов'язків, } \\
\text { можливість кар'єрного зростання, } \\
\text { постійний пошук та залучення } \\
\text { висококваліфрікованих працівників. } \\
\end{array}$ \\
\hline $\begin{array}{c}\text { Природно- } \\
\text { ресурсні }\end{array}$ & $\begin{array}{l}\text { Фактори характеризуються } \\
\text { підвищенням вартості виробничих } \\
\text { ресурсів, неефрективним } \\
\text { використанням ресурсів, збільшення } \\
\text { частки відходів тощо. }\end{array}$ & $\begin{array}{l}\text { Фактори характеризуються рівнем } \\
\text { екологічного стану у регіоні, де } \\
\text { фонкціонує підприємство, доступністю } \\
\text { до сировинних ресурсів або їх } \\
\text { альтернатив тощо. }\end{array}$ \\
\hline Екологічні & $\begin{array}{l}\text { Екологічні фрактори представлені } \\
\text { кількісними показниками негативного } \\
\text { впливу на навколишнє середовище: } \\
\text { обсяг викидів в атмосферу, скидання } \\
\text { води, генерування небезпечних } \\
\text { відходів, відсутність системи } \\
\text { утилізації відходів тощо. } \\
\end{array}$ & $\begin{array}{l}\text { Характеризуються наявністю } \\
\text { капітальних інвестицій в охорону } \\
\text { навколишнього середовища, } \\
\text { зниження або усунення негативних } \\
\text { екологічних впливів, проведення } \\
\text { заходів екологічного спрямування } \\
\text { тощо. } \\
\end{array}$ \\
\hline Інноваційні & $\begin{array}{l}\text { Характеризуються рівнем } \\
\text { інвестиційної привабливості } \\
\text { підприємства, низькою } \\
\text { прогресивністю технології } \\
\text { виробництва, застарілістю виробничої } \\
\text { бази, відсутністю інноваційної } \\
\text { діяльності на підприємстві тощо. } \\
\end{array}$ & $\begin{array}{l}\text { Описуються як спроможність } \\
\text { підприємства фрінансувати } \\
\text { розробки, ефективне використання } \\
\text { інвестиційних ресурсів, наявність } \\
\text { інноваційної політики підприємства } \\
\text { тощо. }\end{array}$ \\
\hline Організаційні & $\begin{array}{l}\text { Організаційні фрактори стосуються } \\
\text { неефективної організаційної } \\
\text { структури управління та } \\
\text { системи мотивації персоналу, } \\
\text { некомпетентності вищого керівництва, } \\
\text { ігнорування корупційних ризиків, } \\
\text { низький рівень дисципліни та довіри } \\
\text { до керівництва тощо. }\end{array}$ & $\begin{array}{l}\text { Характеризуються ефективною } \\
\text { управлінською стратегією, високо } \\
\text { розвиненою корпоративною } \\
\text { культурою, впровадженням Ксв- } \\
\text { практик, наявність кодексу честі } \\
\text { чи комплаєнс політики, ефективна } \\
\text { налагоджена співпраця всіх рівнів } \\
\text { керівництва та працівників тощо. } \\
\end{array}$ \\
\hline
\end{tabular}

Джерело: розроблено авторами

тивності чи неефективного їх використання $€$ фракторами виникнення кризових явищ, а у випадку підвищення результативності та вдосконалення - можуть стати фракторами позитивного впливу на сталий розвиток підприємства. Саме таким чином відображається комплексний, сумарний вплив виділених груп фракторів на ці два різноспрямовані процеси, кожен із яких потребує цілеспрямованих дій вищого керівництва підприємств або стимулюючого або стримуючого характеру. Звідси можемо припустити, що підприємства які впроваджують сталий розвиток у свою діяльність, $€$ менш вразливими до кризових явищ.

Висновки. Поняття кризи та сталого розвитку значно відрізняються за своєю сутністю та проявами в діяльності підприємства. Спільним $\epsilon$ лише те, що обидва процеси спричиняють певні зміни та порушують звичний спосіб функціонування організації. Однак, під час дослідження сракторів виникнення кризових явищ та фракторів забезпечення сталого розвитку підприємства було з'ясовано, що ці чинники здебільшого співпадають і є однаковими для обох 
досліджуваних процесів. Інакше кажучи, негативний прояв даної сукупності фракторів спричиняє кризові явища, а позитивний прояв - сприяє сталому розвитку підприємства. Завдяки результатам даного дослідження також було створено нову гіпотезу про те, що підприємства, які успішно імплементують у свою діяльність стандарти сталого розвитку, є більш стійкими до кризових явищ. Доведення цієї гіпотези на практиці стане наступним етапом дослідження.

\section{СПИСОК ВИКОРИСТАНИХ ДЖЕРЕЛ:}

1. Гринчишин Я. М. Основні підходи до визначення поняття «криза підприємства». Науковий вісник НЛтУ України. 2014. Вип. 24.4. С. 277-283.

2. Штангрет А. М., Воробйов В. І. Криза підприємства: суть, природа виникнення та її вплив на економічну безпеку. Науковий Вісник Львівського державного університету внутрішніх справ. 2010. № 2. С. 324-333.

3. Гречко А. В., Очеретяна О. В. Дослідження еволюції наукової думки в аспектах визначення сутності поняття «сталий розвиток підприємства». Підприємництво та інновації. 2020. Вип. 15. С. 37-41.

4. Кузьміна О. С. Аналіз підходів до трактування поняття «сталий розвиток підприємства». Вісник Хмельницького національного університету: економічні науки. 2015. № 5(1). С. 13-21.

5. Гаврилко П. П., Лалакулич М. Ю., Колодійчук А.В. Основні фрактори виникнення кризових явищ на промислових підприємствах. Науковий вісник НЛтУ України. 2012. Вип. 22.4. С. 158-164.

6. Головач К. С. Узагальнення наукових підходів до поняття «криза на підприємстві». Вісник Житомирського державного технологічного університету. Серія : Економічні науки. 2015. № 1. С. 74-79.

7. Возний С. В., Тюріна Н. М. Сутнісна характеристика кризи підприємств та причини їх виникнення. Наука і економіка. 2017. № 3(7). С. 66-69.

8. Федоренко Т. М. Принципи, фрактори та механізми забезпечення сталого розвитку суб'єктів ринку туристичних послуг України. Ефрективна економіка. 2019. № 12. URL: http://www.economy.nayka.com.ua/?op=1\&z=7542

9. Самофратова В. А. Передумови і фактори сталого розвитку агропродовольчої сфрери. Економіка та держава. 2016. № 10. С. 38-40.

10. Квятковська Л. А. Реалізація принципів концепції сталого розвитку в діяльності підприємства. Вісник соціально-економічних досліджень. 2013. Вип. 1. С. 85-89.

\section{REFERENCES:}

1. Hrynchyshyn, Ya. M. (2014). Osnovni pidkhody do vyznachennia poniattia "kryza pidpryiemstva" [Basic approaches to the definition of "enterprise crisis"]. Naukovyi visnyk NLTU Ukrainy - Scientific Bulletin of NLTU of Ukraine, vol. 24.4, pp. 277-283.

2. Shtanhret, A. M., \& Vorobiov, V. I. (2010). Kryza pidpryiemstva: sut, pryroda vynyknennia ta yii vplyv na ekonomichnu bezpeku [The crisis of the enterprise: the essence, nature and its impact on economic security]. Naukovyi Visnyk Lvivskoho derzhavnoho universytetu vnutrishnikh sprav - Scientific Bulletin of Lviv State University of Internal Affairs, vol. 2, pp. 324-333.

3. Hrechko, A. V., \& Ocheretiana, O. V. (2020). Doslidzhennia evoliutsii naukovoi dumky v aspektakh vyznachennia sutnosti poniattia "stalyi rozvytok pidpryiemstva" [Research of evolution of scientific thought in aspects of definition of essence of concept "sustainable development of the enterprise"]. Pidpryiemnytstvo ta innovatsii - Entrepreneurship and innovation, vol. 15, pp. 37-41.

4. Kuzmina, O. S. (2015). Analiz pidkhodiv do traktuvannia poniattia "stalyi rozvytok pidpryiemstva" [Analysis of approaches to the interpretation of the concept of "sustainable development of the enterprise"]. Visnyk Khmelnytskoho natsionalnoho universytetu: ekonomichni nauky - Bulletin of Khmelnytsky National University: economic sciences, vol. 5(1), pp. 13-21.

5. Havrylko, P. P., Lalakulych, M. Yu., \& Kolodiichuk, A.V. (2012). Osnovni faktory vynyknennia kryzovykh yavyshch na promyslovykh pidpryiemstvakh [The main factors of crisis phenomena in industrial enterprises]. Naukovyi visnyk NLTU Ukrainy - Scientific Bulletin of NLTU of Ukraine, vol. 22(4), pp. 158-164.

6. Holovach, K. S. (2015). Uzahalnennia naukovykh pidkhodiv do poniattia «kryza na pidpryiemstvi» [Generalization of scientific approaches to the concept of "crisis in the enterprise"]. Visnyk Zhytomyrskoho derzhavnoho tekhnolohichnoho universytetu. Seriia: Ekonomichni nauky - Bulletin of Zhytomyr State Technological University. Series: Economic Sciences, vol. 1, pp. 74-79.

7. Voznyi, S. V., \& Tiurina, N. M. (2017). Sutnisna kharakterystyka kryzy pidpryiemstv ta prychyny yikh vynyknennia [The essential characteristics of the crisis of enterprises and the causes of their occurrence]. Nauka i ekonomika - Science and economics, vol. 3(7), pp. 66-69. 
8. Fedorenko, T. M. (2019). Pryntsypy, faktory ta mekhanizmy zabezpechennia staloho rozvytku sub'iektiv rynku turystychnykh posluh Ukrainy [Principles, factors and mechanisms for sustainable development of the market of tourist services of Ukraine]. Efektyvna ekonomika - Efficient economy, vol. 12. Retrieved from: http://www.economy.nayka.com.ua/?op=1\&z=7542 (in Ukrainian)

9. Samofatova, V. A. (2016). Peredumovy i faktory staloho rozvytku ahroprodovolchoi sfery [Prerequisites and factors of sustainable development of the agri-food sector]. Ekonomika ta derzhava - Economy and state, vol. 10, pp. 38-40.

10. Kviatkovska, L. A. (2013). Realizatsiia pryntsypiv kontseptsii staloho rozvytku v diialnosti pidpryiemstva [Implementation of the principles of the concept of sustainable development in the enterprise]. Visnyk sotsialnoekonomichnykh doslidzhen - Bulletin of socio-economic research, vol. 1, pp. 85-89. 